\title{
The Preparation and Properties of Spheroplasts of Aerobacter aerogenes
}

\author{
By J. M. GEBICKI* AND A. M. JAMES \\ Department of Chemistry, Chelsea College of Science and \\ Technology, London, S.W. 3
}

(Received 13 November 1959)

SUMMARY

Cells of Aerobacter aerogenes growing in a nutrient medium were lysed by $1000 \mathrm{u}$. penicillin/ml. When the medium contained penicillin and sucrose, bacterial mass continued to increase on incubation, although no further cell division took place. After growth for $3 \mathrm{hr}$. in the presence of penicillin, all the rod-shaped bacteria were converted to fragile spheroplasts. The internal osmotic pressure of the spheroplasts was estimated by direct counts of the intact cells in solutions containing various concentrations of sucrose, sodium chloride or mixed phosphates. Measurements of optical densities of suspensions were unsuitable for the estimation of the numbers of spheroplasts. Morphological study suggested the existence of a spheroplast cell wall outside the protoplasmic membrane.

\section{INTRODUCTION}

Lysozyme digests the cell walls of several sensitive species of bacteria (Salton, $1953,1954)$. Exposure of such organisms to lysozyme in hypertonic medium results in the release of the bacterial protoplast devoid of cell-wall material (Weibull, 1953; Gooder \& Maxted, 1958; Dark \& Strange, 1957; Brenner et al. 1958). These protoplasts are only stable in high osmotic pressure medium.

The main differences between bacteria and their protoplasts appear in the properties depending on the presence of a cell wall. The intact protoplasts are always spherical in shape and fragile to osmotic and mechanical shock (Weibull, 1953). Under very favourable conditions protoplasts have been observed to divide; the process is slower than with normal cells (McQuillen, 1955).

The preparation of spherical bodies of Escherichia coli exposed to high concentrations of penicillin in hypertonic media (Lederberg, 1956, 1957; Liebermeister \& Kellenberger, 1956; Hahn \& Ciak, 1957) gave experimental confirmation of the suggestion (Duguid, 1946) that penicillin interferes with the synthesis of bacterial cell walls while otherwise allowing growth to proceed. Like protoplasts, the penicillin-induced bodies are spherical and only stable in hypertonic media. Certain observations suggest, however, that penicillin does not completely remove the cell walls of sensitive bacteria (Tomcsik, 1954; Kandler, Hund \& Zehender, 1958; Salton \& Shafa, 1958). The process of reversible vacuolation exhibited by penicillin-

* Present address: Department of Chemistry, Hamilton College, McMaster University, Hamilton, Ontario, Canada. 
induced 'spheroplasts' (Hurvitz, Reiner \& Landau, 1958) of Aerobacter aerogenes suggests the existence of an envelope external to the protoplasmic membrane (Gebicki \& James, 1958). Unlike protoplasts spheroplasts are capable of exponential growth and division (Lark, 1958). Spheroplasts share the fragility and osmotic properties of protoplasts but differ in their method of preparation (Salton, 1957; Chain, Duthie \& Callow, 1945), growth and subsequent formation of normal viable bacteria (Lederberg, 1956).

Growth in the presence of penicillin alters the physical properties of the cell walls, but the nature of the alteration in terms of the chemistry of the structure is still obscure. The reason for the plasticity of the spheroplast envelope may lie in the inability of the cell to incorporate certain cell-wall materials in the presence of penicillin (Park \& Strominger, 1957). On the other hand, a more important factor may be the alteration of the cross-linking rather than the amount of the cell-wall polymer.

In view of these uncertainties, it was considered useful to compare the properties of normal cells and spheroplasts of one organism. The surface properties of Aerobacter aerogenes have already been studied in this laboratory (James, 1957). The organism is not sensitive to lysozyme, even in the presence of versene (Gebicki \& James, 1958; Repaske, 1958) so that comparative studies of its protoplasts were not possible. This paper gives an account of the preparation and properties of penicillin-induced spheroplasts of Aerobacter aerogenes. An account of their electrokinetic behaviour is published elsewhere (Gebicki \& James, to be published).

\section{METHODS}

Organism and culture media. Cultures of Aerobacter aerogenes (NCTC, no. 240) were maintained by monthly subculture in Lab-Lemco broth (Oxoid). For the preparation of spheroplasts the medium was supplemented with magnesium sulphate $(0.2 \%)$ and sucrose $(0.5 \mathrm{M})$. The cultures were incubated at $37^{\circ}$ and usually aerated by gentle shaking. Cultures in defined media (Lowick \& James, 1955) were incubated at $40^{\circ}$ and aerated with a stream of sterile air.

Measurement of cell populations. Optical densities of cell suspensions were measured against the suspension medium in a Unicam S.P. 14,00 spectrophotometer at $600 \mathrm{~m} \mu$. Cell counts were made in a haemocytometer (depth $0.02 \mathrm{~mm}$.) with Thoma rulings.

Microscopy and photomicrography. Cell suspensions in wet films sealed between slide and coverslip were examined with a Reichert Neozet binocular microscope, equipped with a 'Polyphos' condenser. Phase contrast was usually employed. The same system was used for photomicrography.

Reagents. All reagents were of A.R. grade. Crystalline sodium salt of penicillin G (benzylpenicillin) of potency 1670 i.u./mg. (Glaxo Laboratories, Greenford, Middlesex) was stored in the cold before use.

Growth in hypertonic media. Synthetic medium. Rapidly growing cells were suspended in synthetic growth medium and in the same medium supplemented with either glucose $(0.7 \mathrm{M})$, sodium chloride $(1.0 \mathrm{M})$, magnesium sulphate $(1.0 \mathrm{M})$ or mixed sodium and potassium phosphates $(0.5 \mathrm{M})$. The suspensions were incubated without aeration and the optical densities measured at frequent intervals. 
Nutrient medium. Cultures in nutrient broth supplemented with sucrose $(0 \cdot 7 \mathrm{M})$ or glucose $(0.7 \mathrm{M})$ were incubated at $37^{\circ}$ and aerated by shaking. Controls, in which the high concentrations of sugar were omitted, were also included.

The lytic action of penicillin. Cultures rapidly growing in nutrient medium, supplemented with $0.2 \%$ magnesium sulphate, were incubated with various concentrations of penicillin $(0-1000 \mathrm{u} . / \mathrm{ml}$.). Optical densities of samples removed at intervals were determined.

Groroth in the presence of penicillin and sucrose. A young culture containing $7.5 \times 10^{8}$ cells $/ \mathrm{ml}$. was diluted fivefold into fresh nutrient medium containing sucrose and penicillin $(0.6 \mathrm{M}$ and $1000 \mathrm{u}$./ml. respectively). Samples were removed during subsequent incubation at $37^{\circ}$ and their optical densities and cell counts determined. The cultures were aerated by mild shaking.

Standard method for the preparation of spheroplasts. A young (8 hr.) bacterial culture containing about $10^{9} \mathrm{cells} / \mathrm{ml}$. was diluted fivefold into fresh nutrient broth containing magnesium sulphate $(0 \cdot 2 \%)$, sucrose $(0.5-0 \cdot 6 \mathrm{M})$ and penicillin (500$2000 \mathrm{u}$./ml.). After $3 \mathrm{hr}$. incubation with gentle shaking at $37^{\circ}$ the culture was cooled and the spheroplasts harvested at $0^{\circ}$ in the pre-cooled centrifuge. The collected spheroplasts were covered quickly with cold suspension medium and resuspended by gentle agitation. Shaking and warming were avoided. For overnight storage, the spheroplasts were suspended in buffered $1.0 \mathrm{M}$-sucrose or $0.5 \mathrm{M}$-sodium chloride and kept at $0^{\circ}$.

Thermal fragility of the spheroplasts and the effect of formalin. The spheroplasts were harvested and resuspended in $0.2 \mathrm{M}$ solutions of sucrose in $\mathrm{M} / 300 \mathrm{mixed}$ phos-

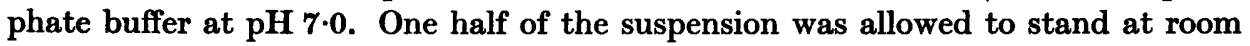
temperature and the other was warmed rapidly to $65^{\circ}$. Changes in the optical densities of the suspensions were followed for $10 \mathrm{~min}$. Samples were examined under phase contrast before and after heating.

Two portions of a similar preparation of spheroplasts in $1.0 \mathrm{M}$-sucrose at $\mathrm{pH} \mathrm{7.0}$ were diluted into $20 \mathrm{vol}$. of the buffered sucrose solution at $0^{\circ}$. Formalin was added to one portion (final concentration $0.5 \%$ ) and both were quickly heated to $60^{\circ}$. Numbers of the intact cells in each sample were determined at intervals. In addition the samples were examined under phase contrast.

Photomicrography of the spheroplasts. Drop samples of bacterial cultures incubated with penicillin in a hypertonic medium were placed between a slide and coverslip and examined under phase contrast. Typical stationary organisms were photographed. No dyes or killing agents were added to the suspensions.

The internal osmotic pressure of the spheroplasts. (a) Optical densities of suspensions. Spheroplasts were suspended in solutions containing various concentrations of sodium chloride or sucrose buffered at pH 7/0. Changes in the optical densities of suspensions were followed, frequently over several hours.

(b) Lysis in sucrose solutions. $\mathbf{0 . 5} \mathrm{ml}$. portions of a thick suspension of spheroplasts in $1.0 \mathrm{M}$-sucrose were diluted into $9.5 \mathrm{ml}$. of solutions containing various concentrations of sucrose at $\mathrm{pH} 7 \cdot 0$. The suspensions were incubated at $25 \pm 0 \cdot 1^{\circ}$, samples withdrawn at intervals, treated with formalin, to preserve the spheroplasts, and cell counts determined.

(c) Lysis in sodium chloride solutions. Spheroplasts in $0.5 \mathrm{M}$ buffered solution of sodium chloride were diluted with salt solutions at $\mathrm{pH} 7 \cdot 0$. The final concentrations 
of sodium chloride were $0.05-0.5 \mathrm{M}$. The numbers of intact spheroplasts remaining in suspension after incubation at $\mathbf{2 5}^{\circ}$ were determined by direct counting.

(d) Lysis in mixed phosphate buffer solutions. In a similar experiment, the spheroplasts were incubated in solutions containing various concentrations of phosphates. These were obtained by mixing and diluting equal volumes of $\mathrm{m} / 3$ disodium hydrogen phosphate and potassium dihydrogen phosphate. Intact spheroplasts were counted as previously.

Optical properties of suspensions of spheroplasts. Spheroplasts were suspended in hypertonic solutions and changes in the optical densities of the suspensions with time were measured. The variables investigated were the osmotic pressure, $\mathrm{pH}$ and electrolyte contents of the solutions.

\section{RESULTS}

Penicillin lyses cells of Aerobacter aerogenes growing in a simple synthetic medium (Gebicki, 1959), but the high solute concentrations required to preserve any formed spheroplasts prevented cell division altogether. Since the antibiotic acts only on actively growing bacteria, the synthetic medium could not be used for the preparation of spheroplasts.

On the other hand, the mean generation time of the nutrient broth cultures containing $0.7 \mathrm{M}$-sucrose were the same as those of control suspensions ( $30 \mathrm{~min}$.). This was even reduced when glucose was the added solute, but as sucrose is the most commonly used substance for the stabilization of protoplasts, it was used in further experiments.

The lytic action of penicillin on cells growing in the nutrient medium is shown in Fig. 1. The rate of growth is affected by penicillin concentrations above $10 \mathrm{u} . / \mathrm{ml}$. At $100 \mathrm{u}$./ml., normal growth was restored after $4 \mathrm{hr}$. incubation. The initial increase of the optical densities of suspensions containing the highest concentrations of penicillin used indicates that the mass of cells is approximately doubled before the onset of lysis.

The nutrient medium was suitable for the production of spheroplasts since it did not prevent bacterial growth when supplemented with high concentrations of sucrose and, further, suitable amounts of penicillin lysed the cells growing in it. In Fig. 2 the mass of cells growing in the medium containing sucrose in the presence of $1000 \mathrm{u} . / \mathrm{ml}$. of penicillin is compared with the actual number of cells per ml. of suspension. A series of photomicrographs illustrate a typical sequence of changes which the normal cells (Pl. 1, fig. 1) undergo under the influence of penicillin. Characteristic protoplasmic protrusions were formed $\mathbf{3 0} \mathrm{min}$. after the exposure to penicillin (Pl. 1, figs. 2, 3). Further incubation led to the increase of the size of the protrusions (Pl. 1, figs. 4, 5), detachment of the rod-shaped fragments and the appearance of characteristic vacuolated spheroplasts (P1. 2, figs. 6-8). When the external osmotic pressure was carefully lowered by the addition of water, the protoplasm expanded in the initially vacuolated spheroplast and, after breaking through the confining barrier, formed a spherical protrusion outside the spheroplast proper (Pl. 2, fig. 9). The protrusion then expanded at the expense of the spheroplast, the protoplasm gradually leaving the original cell. After a short time (2-3 min.) the new sphere burst leaving no clearly defined structure. A normal 'ghost' was left 
by the spheroplast (Pl. 2, fig. 10). Frequently the whole process was so rapid that the change from spheroplast to 'ghost' appeared to proceed directly. However, the controlled lysis was observed on numerous occasions.

The process of vacuolation could be reversed by placing the spheroplasts in media of lower osmotic pressure. On subsequent addition of sucrose or sodium chloride, the vacuoles formed again. This could be repeated several times.

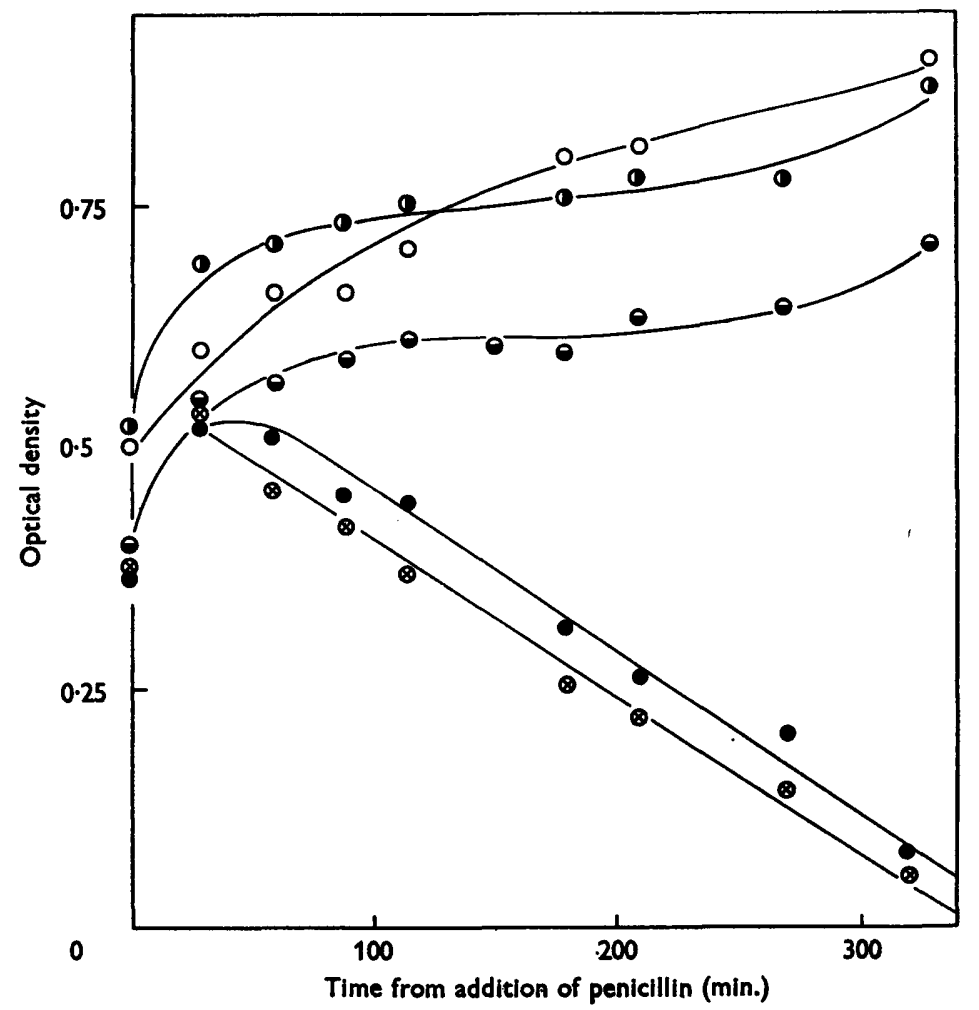

Fig. 1. The lytic effect of penicillin in nutrient media. $O$, Control; $O, 10 \mathrm{u}$. penicillin/ ml. ; $\ominus, 100$ u. penicillin/ml. ;, 1000 u. penicillin/ml.; $\otimes, 2000$ u. penicillin/ml.

The lack of correlation between the actual numbers of intact spheroplasts and the optical density of the suspension is shown in Fig. 3. The optical density curve suggests a continuous decrease in the number of cells which does not actually occur. Several other experiments, in which the concentration of the stabilizing solute was the independent variable, emphasized the unsuitability of the method for the determination of the spheroplast populations.

The effectiveness of sucrose and sodium chloride in the preservation of intact spheroplasts at different osmotic pressures is shown in Fig. 4. The figure taken as $100 \%$ preservation for the given solute was obtained by averaging the numbers of spheroplasts per unit volume of suspension after $1 \mathrm{~min}$. standing in solution of osmotic pressure above 5 atmospheres. Values above $90 \%$ must be regarded as complete preservation in view of the errors involved. Comparative studies for 
sodium and potassium phosphates were not made because of the difficulty of obtaining accurate values for the osmotic pressures of their solutions. Some indication of the stabilizing action of the phosphates is seen in Fig. 5. Spheroplasts suspended in $M / 6$ buffer solution were counted before and after storage for $24 \mathrm{hr}$. at $0^{\circ} \mathrm{C}$.; the counts were 279 and $234 \times 10^{6}$ cells $/ \mathrm{ml}$. of suspension respectively.

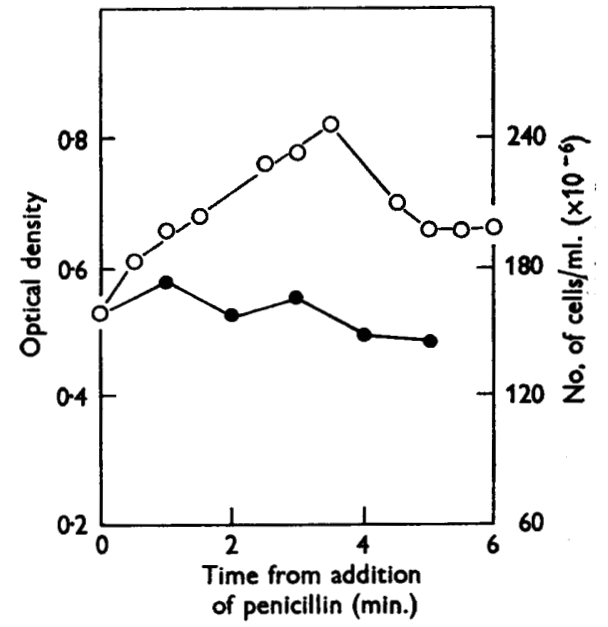

Fig. 2

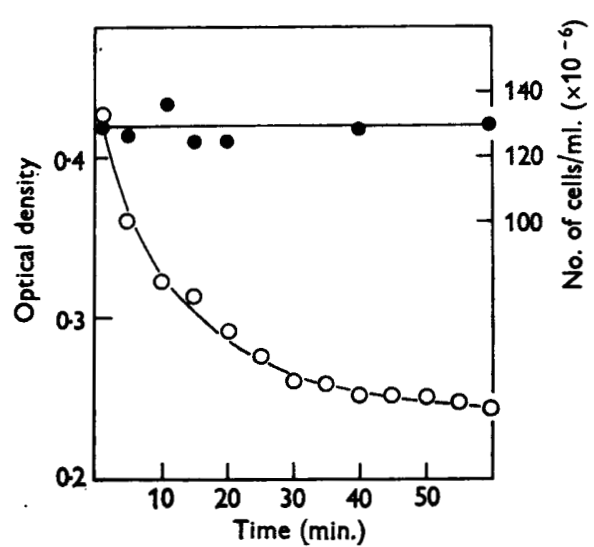

Fig. 3

Fig. 2. Growth of Aerobacter aerogenes in presence of sucrose and penicillin. O, Optical density, i.e. bacterial mass; $O$, no. of cells.

Fig. 3. Spheroplasts suspended in $7 \%$ sucrose at $\mathrm{pH} 6.8$ and $20^{\circ} \mathrm{C}$. $\mathrm{O}$, Optical density; , no. of cells.

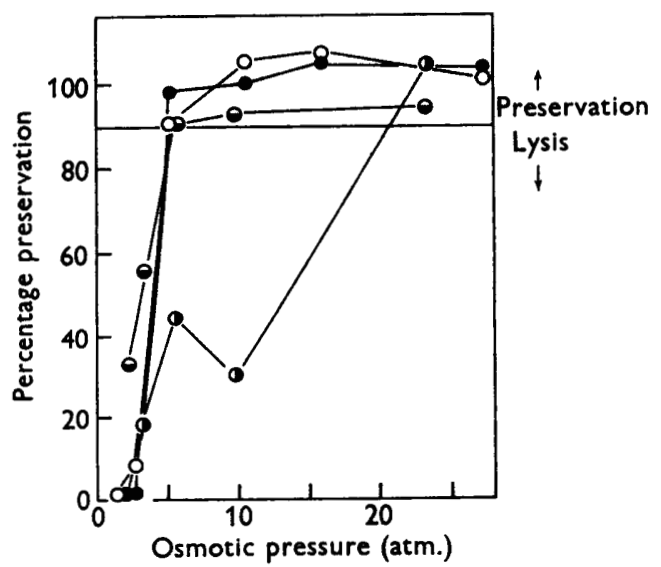

Fig. 4

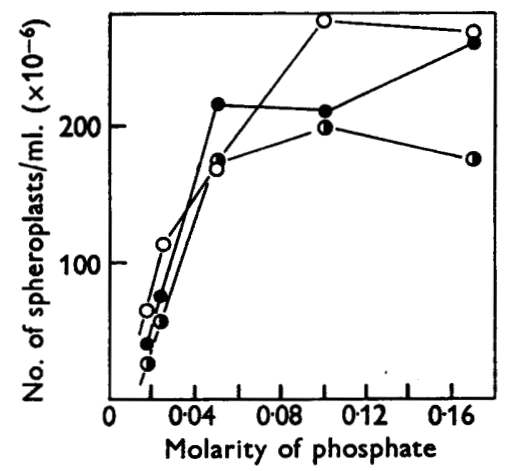

Fig. 5

Fig. 4. Stability of spheroplasts in solutions of sucrose and sodium chloride at $25^{\circ} \mathrm{C}$. Sucrose, $O$, after 60 min., $\odot$, after $20 \mathrm{hr}$.; $\mathrm{NaCl}, \odot$, after $60 \mathrm{~min}$., $(1$, after $23 \mathrm{hr}$.

Fig. 5. Stability of spheroplasts in mixed phosphate buffer solutions at $25^{\circ} \mathrm{C}$. $\bigcirc$, After 5 min., after 30 min., $O$, after $18 \mathrm{hr}$. 
An attempt to discover the factors responsible for the anomalous optical properties of suspensions of spheroplasts is summarized in Table 1 . Changes in the optical densities of the suspensions were followed under identical conditions for $1 \mathrm{hr}$. All solutions were buffered with mixed phosphates unless otherwise stated. Since it has been demonstrated (Fig. 3) that a decrease in the optical density of $46 \%$ can occur without lysis, values less than this figure can be assumed to be due to factors other than destruction of the spheroplasts. This was, in fact, confirmed by microscopic examination of cell suspensions. Some cell damage occurred at pH $7 \cdot 5$, both at $20^{\circ}$ and at $37^{\circ}$. Trypsin had no accelerating effect on lysis. A certain regularity of the pattern of changes in the optical densities of suspensions with $\mathrm{pH}$ suggests that even at $\mathrm{pH} 7 \cdot 5$ lysis may be fairly rapid. An experiment in which a wide range of $\mathrm{pH}$ values was used suggested that at neutral $\mathrm{pH}$ there was no lysis, while below pH $4 \cdot 3$ the optical densities of suspensions increased. Spheroplasts in acid buffers appeared as highly refracting irregular bodies and they did not lyse on resuspension in distilled water. Spheroplasts suspended at pH 3.5 for $1 \mathrm{hr}$., collected by centrifugation and resuspended at $\mathrm{pH} 6 \cdot 7$, behaved normally, indicating that the effect of the acid was reversible.

Table 1. Relationship between lysis and percentage lowering of the optical densities of suspensions of spheroplasts

\begin{tabular}{|c|c|c|c|c|}
\hline Suspension medium & $\begin{array}{l}\text { Temp. } \\
\left({ }^{\circ} \mathrm{C} .\right)\end{array}$ & pH & $\begin{array}{l}\text { \% lowering of } \\
\text { optical density } \\
\text { after } 1 \mathrm{hr} \text {. }\end{array}$ & Lysis \\
\hline $7 \%$ sucrose & 20 & $6 \cdot 8$ & 46 & - \\
\hline $10 \%$ sucrose & 37 & $7 \cdot 5$ & 57 & $(+)$ \\
\hline $10 \%$ sucrose + trypsin & 37 & $7 \cdot 5$ & 54 & $(+)$ \\
\hline $10 \%$ sucrose & 20 & $7 \cdot 5$ & $\mathbf{5 0}$ & $(+)$ \\
\hline $10 \%$ sucrose & 20 & $\mathbf{3 \cdot 4}$ & -47 & - \\
\hline $10 \%$ sucrose + pepsin & 20 &, $\mathbf{3 \cdot 4}$ & -14 & - \\
\hline $20 \%$ sucrose + phosphate buffer & 20 & $6 \cdot 7$ & 32 & - \\
\hline $20 \%$ sucrose + citrate buffer & 20 & $6 \cdot 7$ & 27 & - \\
\hline $7 \%$ sucrose + phosphate buffer & 20 & $6 \cdot 8$ & 41 & - \\
\hline $7 \%$ sucrose + citrate buffer & 20 & 6.8 & 32 & - \\
\hline
\end{tabular}

$(+)$, Slight lysis confirmed by microscopic examination.

\section{DISCUSSION}

The term spheroplasts has been suggested to describe abnormal bacterial forms fragile to osmotic and mechanical shock, spherical in shape and released by the action of penicillin on the rapidly growing cells: spheroplasts of Escherichia coli lyse rapidly when warmed to $56^{\circ}$ (Hurwitz et al. 1958). The description of the fragile, spherical forms of Aerobacter aerogenes as spheroplasts can be justified on several grounds.

Normal growth precedes lysis of cells exposed to penicillin during a period corresponding to the doubling of the bacterial mass in suspension (Fig. 1). That this is not accompanied by actual cell division is shown by direct cell counts (Fig. 2). Thus, during the initial period of exposure to the inducing agent, the cell-growth mechanism is not damaged, but division ceases. Growth continues, at a diminished rate, for a further $3 \mathrm{hr}$. During this time the individual cells undergo a series of changes which result in the production of the spherical forms. The synthesis of cell 
material is counterbalanced by a process of gradual lysis, the optical density of the culture becoming constant about $5 \mathrm{hr}$. after the initial exposure to penicillin.

The internal osmotic pressure of the spheroplasts lies between 5 and 6 atmospheres at $25^{\circ} \mathrm{C}$. This compares well with the value for Escherichia coli estimated by a different method (Mitchell \& Moyle, 1956), and suggests that the spheroplast envelopes have decreased tensile strength. The superiority of sucrose in the stabilization of spheroplasts can be explained if it is assumed that the cells possess a mechanism for the active transport of $\mathrm{K}^{+}$and $\mathrm{PO}_{4}^{---}$.

Various workers have confirmed a direct relation between lysis and turbidities of suspensions of protoplasts and bacteria (Mitchell \& Moyle, 1956; Salton, 1957; Christian \& Ingram, 1959). Turbidity measurements, however, cannot be applied to the estimation of the numbers of spheroplasts remaining in suspension. The most highly organized fragments visible after lysis of bacteria by lysozyme are the cytoplasmic membranes and the associated lipid granules. These 'ghosts' are difficult to observe under the microscope (Weibull, 1955). In contrast, the spheroplast 'ghosts' appear to be more dense optically (Pl. 2, fig. 10) and they frequently flocculate. Extensive vacuolation of the spheroplasts in response to the external osmotic conditions may also explain their unexpected optical properties. Bacteria are difficult to plasmolyse and the extent of shrinkage is usually slight (Weibull, 1956). Volumes of protoplasts vary slightly with the external conditions, the osmotically inert fraction of the total volume being $36 \%$ for protoplasts of Bacillus megaterium (Weibull, 1955) and $76 \%$ for those of Micrococcus lysodeikticus (Gilby \& Few, 1959). The process of vacuolation of the spheroplasts is rather slow; this probably accounts for the continuous changes in the optical densities of their suspensions (Fig. 3).

Lysis of spheroplasts at high temperatures and at values of $\mathrm{pH}$ greater than $\mathbf{7 \cdot 0}$ must be the result of a rupture in the protoplasmic membrane. In alkaline conditions the membrane constituents are probably slowly denatured, the process resulting in alteration and breakdown of the structure. Such changes do not occur in acid conditions, but it is surprising to note the profound alteration of the physical properties of the protoplasm at $\mathrm{pH}$ values below 4.3. Resistance of the acid-treated protoplasts to lysis is probably due to the coagulation of the cell contents. The process is reversible even after prolonged standing at pH 3.5. It is interesting to speculate whether such changes occur in normal bacteria, whose viability may not be affected by acid treatment.

The swellings and protrusions observed in bacteria exposed to penicillin in hypertonic media are first visible after $30 \mathrm{~min}$. incubation, i.e. at the time corresponding to the onset of osmotic fragility. The protrusions appear in the middle of the bacteria, where the cells would be expected to divide. Protrusions continue to grow, until finally the remaining rod-shaped fragments become detached, leaving the large spheres. In $5 \mathrm{hr}$. the surface area of a normal cell converted to a spheroplast increases by a factor of about 70.

The presence of an envelope around the spheroplasts of Aerobacter aerogenes which can be differentiated from the protoplasmic membrane is suggested by the examination of the vacuolated bodies. The protoplasm must at all times be surrounded by a hydrophobic membrane if lysis is not to take place. In hypertonic solution, the membrane becomes detached from the inside of the envelope which 
surrounds the spheroplast and which remains clearly visible (Pl. 2, fig. 8). The vacuole then occupies the space between the protoplasmic membrane and the spheroplast cell wall. The two structures can be demonstrated by observing the emergence of a protoplasmic extrusion from within the spheroplast (Pl. 2, fig. 9). Bacterial protoplasts are surrounded by the protoplasmic membranes only and do not develop vacuoles. Although their size varies slightly with the external osmotic pressure, they remain spherical in shape. It is interesting to note that many authors have observed the presence of vacuoles in spheroplasts, without commenting on the implication of the phenomenon (Lederberg, 1956; Liebermeister \& Kellenberger, 1956; Hahn \& Ciak, 1957; Lark, 1958, McQuillen, 1958).

The results obtained support the hypothesis that bacterial spheroplasts are surrounded by a modified form of cell wall in addition to the protoplasmic membrane. This is further confirmed by a comparison of the electrokinetic properties of the normal cells and spheroplasts (Gebicki \& James, to be published).

The authors acknowledge gratefully financial support for this work by the British Empire Cancer Campaign.

\section{REFERENCES}

Brenner, S. et al. (1958). Bacterial protoplasts. Nature, Lond. 181, 1713.

Chain, E., Duthie, E. S. \& CaLlow, D. (1945). Bactericidal and bacteriolytic action of penicillin on the staphylococcus. Lancet, 248, 652.

Christian, J. H. B. \& Ingram, H. (1959). Lysis of Vibrio costicolus by osmotic shock. J. gen. Microbiol. 20, 32.

Dark, F. A. \& Strange, R. E. (1957). Bacterial protoplasts from Bacillus species by the action of autolytic enzymes. Nature, Lond. 180, 759.

DUGUID, J. P. (1946). The sensitivity of bacteria to the action of penicillin. Edinb. med. J. 53, 401.

Gebicki, J. M. (1959). Some Physical Studies of the Effects of Antibacterial Agents and Enzymes on Bacterial Surfaces. Ph.D. Thesis, London University.

GEBICKI, J. M. \& J JMEs, A. M. (1958). Effect of some lytic agents on Aerobacter aerogenes. Nature, Lond. 182, 725.

GiLby, A. R. \& FEw, A. V. (1959). Osmotic properties of protoplasts of Micrococcus lysodeikticus. J. gen. Microbiol. 20, 321.

Gooder, H. \& MAXTed, W. R. (1958). Protoplasts of group A $\beta$-haemolytic streptococci. Nature, Lond. 182, 808.

Hahn, F. E. \& CIAK, J. (1957). Penicillin-induced lysis of Escherichia coli. Science, 125, 119.

Hurwitz, C., Reiner, J. M. \& Landau, J. V. (1958). Studies in the physiology and biochemistry of penicillin-induced spheroplasts of Escherichia coli. J. Bact. 76, 612.

JAMEs, A. M. (1957). The electrochemistry of the bacterial surface. Progr. Biophys. 8, 98.

Kanduer, O., Hund, A. \& Zehender, C. (1958). Cell-wall composition in bacterial and L-forms of Proteus vulgaris. Nature, Lond. 181, 572.

LARK, K. G. (1958). Abnormal growth induced by penicillin in a strain of Alcaligenes fecalis. Canad. J. Microbiol. 4, 165.

LEDerberg, J. (1956). Bacterial protoplasts induced by penicillin. Proc. nat. Acad. Sci., Wash. 42, 574.

LEDERBERG, J. (1957). Mechanism of action of penicillin. J. Bact. 73, 144.

Liebermeister, K. \& Kellenberger, E. (1956). Studien zur L-Form der Bakterien. Z. Naturforsch. 11, 200.

Lowick, J. H. B. \& JAMEs, A. M. (1955). The electrokinetic properties of Aerobacter aerogenes. Biochem. J. 65, 431. 
McQuinuen, K. (1955). Bacterial protoplasts. Growth and division of protoplasts of Bacillus megaterium. Biochim. biophys. Acta, 18, 458.

MCQuILLEN, K. (1958). Lysis resulting from metabolic disturbance. J. gen. Microbiol. 18, 498.

Mrtchell, P. \& Moxue, J. (1956). Osmotic structure and function in bacteria. Bacterial Anatomy. Symp. Soc. gen. Microbiol. 6, 150.

Park, J. T. \& Strominger, J. L. (1957). Mode of action of penicillin. Science, 125, 99.

REPASKe, R. (1958). Lysis of Gram-negative organisms and role of versene. Biochim. biophys. Acta, 30, 225.

Salton, M. R. J. (1953). Cell structure and the enzymic lysis of bacteria. J. gen. Microbiol. 9, 512.

Salton, M. R. J. (1954). The action of lysozyme on the cell walls of certain bacteria. J. gen. Microbiol. 11, ix.

Salton, M. R. J. (1957). The properties of lysozyme and its action on micro-organisms. Bact. Rev. 21, 82.

Salton, M. R. J. \& Shafa, F. (1958). Some changes in the surface structure of Gramnegative bacteria induced by penicillin action. Nature, Lond. 181, 1321.

ToмcsIK, J. (1954). Über die Oberflächenstrukturen des Bacillus anthracis. Schreiz. Z. allg. Path. 17, 457.

Werbuld, C. (1953). The isolation of protoplasts from Bacillus megaterium by controlled treatment with lysozyme. J. Bact. 66, 688.

WeIBULl, C. (1955). Osmotic properties of protoplasts of Bacillus megaterium. Exp. Cell Res. 9, 294.

Werbull, C. (1956). Bacterial Protoplasts. Bacterial Anatomy. Symp. Soc. gen. Microbiol. 6, 111 .

\section{EXPLANATION OF PLATES}

Anoptral Phase Contrast, 3500

Plate 1

Fig. 1. Normal cells of Aerobacter aerogenes.

Figs. 2, 3. After $30 \mathrm{~min}$. incubation with sucrose and penicillin.

Fig. 4. After $60 \mathrm{~min}$.

Fig. 5. After 2 hr.

Plate 2

Figs. 6-8. Vacuolated spheroplasts.

Fig. 9. Protoplast emerging from within a spheroplast, only after careful water treatment.

Fig. 10. Spheroplast ghost, after extreme dilution with water. 

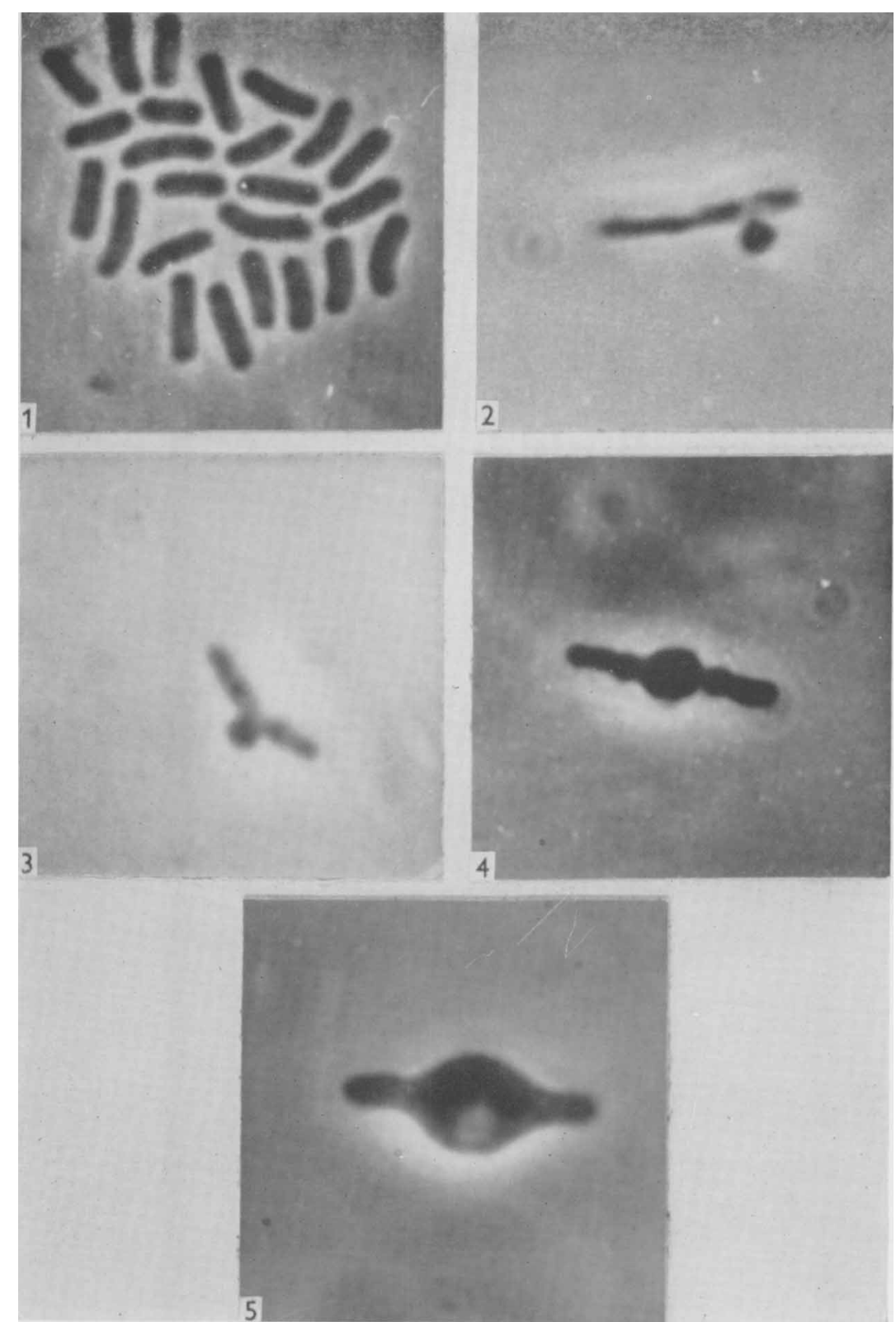

J. M. GEBICKI AND A. M. JAMES 
Journal of General Microbiology, Vol. 23, No. 1

Plate 2

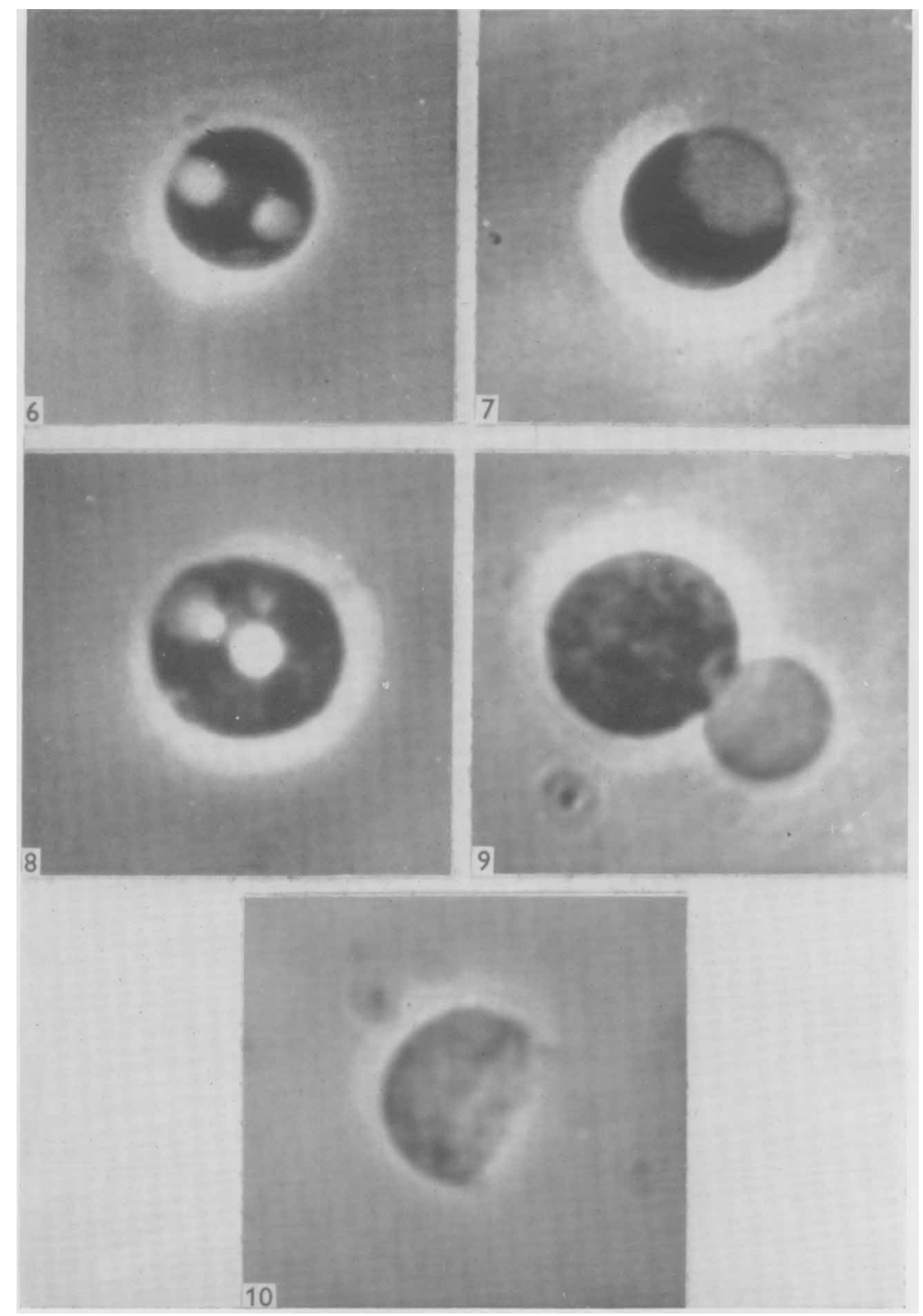

J. M. GEBICKI AND A. M. JAMES 